\title{
Design of vascular endothelium-specific drug-targeting strategies for the treatment of cancer
}

\author{
Grietje Molema ${ }^{\bowtie}$ \\ University Medical Center Groningen, University of Groningen, Department Pathology and Laboratory Medi- \\ cine, Medical Biology section, Endothelial Cell and Vascular Drug-targeting Research, Groningen, Netherlands; \\ 邓e-mail: g.molema@med.umcg.nl
}

Received: 05 April, 2005; revised: 08 June, 2005; accepted: 10 June, 2005 available on-line: 25 June, 2005

\begin{abstract}
Tumor endothelial cells are actively involved in the neovascularization processes that accompany tumor growth. Their easy accessibility for systemically applied therapeutics makes them interesting targets for therapeutic intervention. Especially for drug targeting-based therapeutics that often consist of macromolecular moieties, the tumor endothelium is considered a much better target than the tumor cells located behind the vascular wall barrier. In this review, the general principles underlying the development and choices in the development of vascular drug-targeting strategies are discussed. An overview of target epitopes identified in the past two decades is followed by a summary of those strategies that directly or indirectly induced tumor blood flow blockade in vivo. The demonstrated therapeutic success in pre-clinical animal models in debulking large tumor masses and inhibiting tumor outgrowth warrant further development of these therapeutic approaches. Yet, more effort should be put in studies in which the efficacy of different effector activities aimed at the same target, of one effector activity aimed at different targets, and of multiple target strategies are be compared. Combining these data with proper inventories on the molecular basis of tumor endothelial heterogeneity in general will make possible the development of tumor vascular drug-targeting strategies towards clinical application.
\end{abstract}

Keywords: vascular drug-targeting, angiogenesis, cancer

Neovascularization is a hallmark of tumor growth. The newly formed blood vessels supply the proliferating tumor cells with nutrients and oxygen. Endothelial cells are central in this neovascularization process. They respond to the hypoxic conditions by migration into the hypoxic area, proliferation, and blood vessel support cell recruitment that eventually leads to stabilization of the newly formed vessel. Furthermore, they continuously recruit leukocytes from the circulation that in turn can stimulate neovascularization. Considering their central role in these processes and their direct accessibility for drugs via the blood circulation, tumor vascular endothelial cells are important target cells for therapeutic intervention in cancer.

This review will address new advances in the development of vascular drug-targeting approaches for the treatment of cancer. After introducing the basic principles of drug-targeting, a short summary of target epitopes on tumor endothelial cells identified in the last two decades will be provided. Different examples of the design of macromolecular drugtargeting constructs and their anti-tumor effects in pre-clinical models will be discussed. Lastly, some essential issues to be solved in the coming years to bridge the gap between the pre-clinical studies and clinical application of tumor vascular drug-targeting strategies will be addressed.

\section{DRUG-TARGETING}

The main aim of drug-targeting therapies is to increase the efficacy, and reduce the toxicity of

- Presented at the XXXII Winter School, 3-7 March 2005, Zakopane, Poland.

Abbreviations: Ang, angiopoietin; DT, diphteria toxin; EDB-Fn, EDB-oncofetal domain of fibronectin; HDL, high density lipoprotein; IL-1 $\beta$, interleukin-1 $\beta$; iNOS, inducible nitric oxide synthase; LDL, low density lipoprotein; MHC, major histocompatibility complex; MMP, matrix metalloproteinase; NO, nitric oxide; RGD, Arg-Gly-Asp (arginine-glycine-aspartic acid); ScFv, single chain antibody variable fragment; siRNA, small interfering RNA; TNF $\alpha$, tumor necrosis factor- $\alpha$; VCAM-1, vascular cell adhesion molecule-1; VEGF (R), vascular endothelial cell growth factor (receptor). 
drugs. Drugs in this respect include pharmacologically active substances such as therapeutic genes, siRNAs, antisense oligodeoxynucleotides, chemotherapeutics, toxic molecules, and chemical inhibitors of signal transduction. Increase in efficacy and / or reduction in toxicity is achieved by incorporating the drug in a carrier or vehicle. The carrier selectively binds to the target cells by virtue of intrinsic specificity, or incorporation of homing ligands with selectivity for the target epitopes. After binding, internalization of carrier-complexed drug will be followed by intracellular drug release, although in some instances extracellular delivery will suffice for the effect (Fig. 1). The behaviour of the carrier molecules largely determines the pharmacokinetic behaviour and cellular distribution of the drug. Furthermore, selective delivery of the drug into the target cells may allow achievement of higher drug concentrations in the target cells or even in specific compartments of the target cells. As a result, drug efficacy can be enhanced. With the advent of powerful molecular biological techniques, molecular mechanisms of disease become unravelled at a fast pace. As a result, new chemical and biotechnologi-

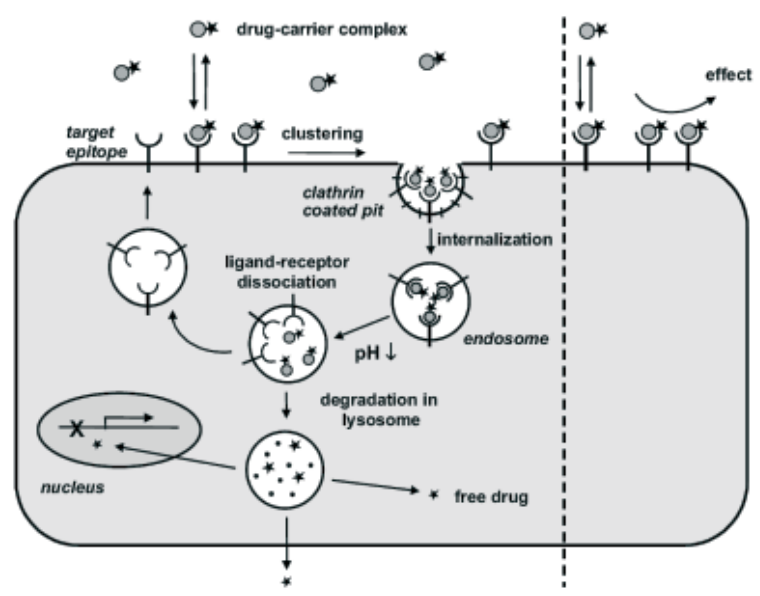

Figure 1. Schematic representation of the drug-targeting concept.

The drug-carrier complex binds to epitopes on the target cells due to its intrinsic specificity for the target or due to specificity created by homing ligands such as peptides and antibodies. Upon binding, the drug-carrier construct is either internalized (left) or stays at the outside of the cells (right). In the case of internalization, the transport via early endosomes into lysosomes will lead to drug-carrier construct degradation, either as a result of $\mathrm{pH}$ drop or as a result of enzymatic degradation. The drug is released into the cytoplasm, after which it can find its molecular target in the cell or redistribute to the cell's exterior. When the target epitope is a non-internalizing epitope, the activity of the targeted drug will be at the outside of the cell. Examples of the drug-targeting approaches that require internalization are delivery of toxins, plasmids, and apoptosis-inducing compounds. For the delivery of cytolytic activity to kill tumor endothelium and of blood coagulation inducing factors, the non-internalizing route suffices (from Schraa et al., 2002a). cal entities are generated that in principle can exert potent effects on disease processes but may have deficient bio-stability or distribution to the areas of disease. In addition, they often exert strong toxicity upon getting access to healthy tissue. Furthermore, the chemical characteristics of these new compounds may be such that their access to the site of action, in particular to intracellular target enzyme systems, is minimal. By covalently attaching them to or incorporating into carrier molecules, the whole body and cellular disposition of these drugs can be considerably manipulated (Molema \& Meijer, 2001).

Carriers can be divided in particle-type, soluble and cellular carriers. Particle-type carriers include liposomes, lipid particles (low and high density lipoproteins, LDL and HDL, respectively), microspheres and nanoparticles, and polymeric micelles. Soluble carriers comprise monoclonal antibodies and fragments thereof, modified plasma proteins, peptides, polysaccharides, and biodegradable carriers consisting of polymers of various chemical composition. For the site-selective delivery of genes, vectors such as liposomes, lipid complexes, polymers and viruses are exploited. In some cases, immune effector cells and stem cells have been employed as vehicles to specifically deliver effector activities to the target tissue. In Fig. 2, an overview of the most frequently used carrier molecules studied as treatment modalities in tumor vascular drug-targeting strategies is given.

In general, carrier molecules are modified with targeting ligands that specifically bind to target epitopes on the tumor endothelial cells, harnessing the construct with cell specificity. Although untargeted constructs can accumulate in extravascular spaces in tumor tissue due to locally enhanced permeability (Maeda et al., 2000), the focus of this review will be on constructs that actively target and deliver drugs to or into tumor endothelial cells. Monoclonal antibodies harbor intrinsic specificity for a target epitope, yet have the disadvantage of low drug loading capacity while maintaining antigen binding and pharmacokinetic characteristics. Therefore, they are often used as targeting ligands by coupling them to carriers with high drug-loading capacity (Everts et al., 2003; Kok et al., 2001). The use of peptide and antibody fragment expressing phage display libraries has led to the identification of molecules that specifically bind to tumor endothelial cells without the requirement of knowing the identity of the target epitope (Mutuberria et al., 2001). An advantage of peptide-based ligands over antibody fragments is that the former ones often bind in a species-independent way to their target molecules. Antibodies raised against, e.g., adhesion molecules, in contrast, frequently do not cross-react with similar structures of different species (Schraa et al., 2002a). The major advantage of this cross-species recognition is that it 
facilitates the step from pre-clinical to clinical testing of drug-targeting constructs.

To choose the proper target and the proper pharmacological entity for inclusion in drug-targeting constructs, knowledge on the molecular control of endothelial behavior during tumor-induced angiogenesis is essential. Therefore, a short description of the cellular and molecular processes involved in those events is given.

\section{ENDOTHELIAL CELL FUNCTION IN NORMAL PHYSIOLOGICAL PROCESSES}

The blood vessels in our body are highly heterogeneous with regard to architecture and function. The larger blood vessels consist of endothelial cells, smooth muscle cells, connective tissue and elastic elements, and are mainly responsible for transporting blood through the body. The endothelium in larger vessels is actively involved in blood pressure control via, among others, release of the vasodilator prostacyclin and the vasorelaxant nitric oxide (NO) as well as the production of vasoconstrictors including endothelin-1 and the arachidonic acid metabolites thromboxane A2 and prostaglandin H2 (Vane et al., 1995). In contrast, in the microvascular, capillary bed of organs, the endothelial cells reside on a basal lamina and are only supported by sparsely distributed pericytes that facilitate vessel maturation and vascular integrity (Hellstrom et al., 2001).

Endothelial cells exert four main functions. They serve as a (semipermeable) barrier to transport of soluble molecules and maintain haemostatic balances via the production of anti-coagulants such as thrombomodulin, tissue factor pathway inhibitor, and procoagulants including von Willebrand factor and tissue factor. Other factors including thrombin, antithrombin and heparan sulfate proteoglycans, platelet activating factor and platelet factor- 4 also play a prominent role in haemostatic control by the vessel wall in conditions of physical damage and cellular stress (Vane et al., 1995).

Coordinated recruitment of leukocytes into underlying tissue as a result of an inflammatory insult is another essential task of endothelial cells (Von Andrian \& Mackay 2000; Pober, 2002). This process takes place in the postcapillary venules in microvascular beds of all organs (except the spleen, lungs and liver), after activation of endothelial cells by pro-inflammatory cytokines such as tumor necrosis factor (TNF)- $\alpha$ and Interleukin (IL)-1 $\beta$.

The last process in which endothelial cells play a prominent role is new blood vessel formation or angiogenesis. During angiogenesis a complex interplay between endothelial cells, smooth muscle cells and/or pericytes, fibroblasts and leukocytes takes place. Angiogenesis occurs during many physiological processes in the body, including wound healing and placental growth during pregnancy. In chronic inflammatory diseases, angiogenesis provides the tissue with a means to facilitate ongoing leukocyte recruitment and supply sufficient amounts of oxygen and nutrients to support continuous cellular activation and cell death induction (Paleolog, 2002; Fearon et al., 2003). In growing tumors, hypoxic conditions and/or disbalance in the production of pro- and anti-angiogenic factors via oncogenic transformation of tumor cells are conditions that activate the capillary bed endothelial cells to become pro-an-

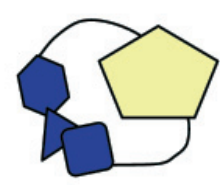

Peptides

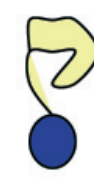

Growth

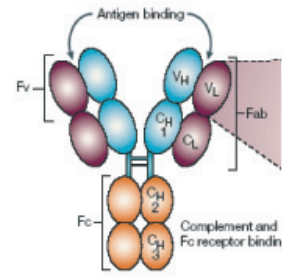

Antibodies

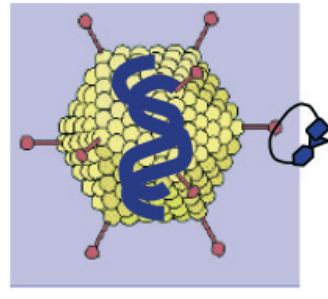

Viruses

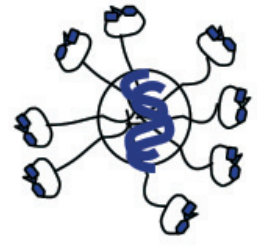

Polymer based nanoparticles

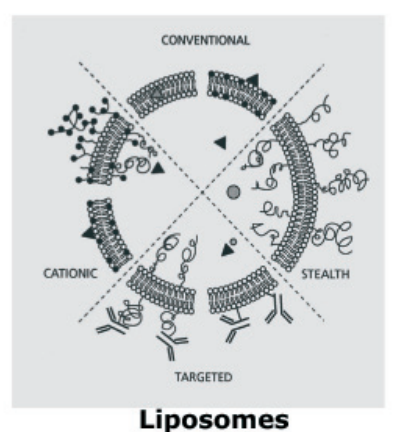

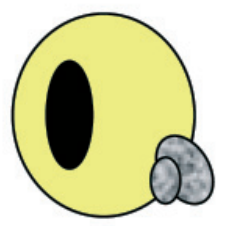

Immune effector cells

Figure 2. Examples of drug-targeting devices developed in recent years for tumor vascular endothelium-directed therapies. See text for more details on their application. 
giogenic (Bergers \& Benjamin, 2003). A direct relation between leukocyte-endothelial cell interactions in the control of (tumor) angiogenesis has also been implicated in various studies (Reinders et al., 2003; Voronov et al., 2003).

\section{MOLECULAR CONTROL OF TUMOR ANGIOGENESIS}

Tumor angiogenesis differs significantly from normal angiogenesis. The vascular network in growing tumors is structurally and functionally abnormal, with tortuous, dilated blood vessels, aberrant blood flow and hyper-permeable regions. Within the network, the endothelium is highly heterogeneous with respect to activation status, as exemplified by differential expression of vascular markers, and vessel maturation is delayed (Bergers \& Benjamin, 2003).

Tumor blood vessels can form from pre-existing vessels by angiogenic sprouting or by intussusceptive growth. In addition, circulating endothelial progenitors can contribute to tumor angiogenesis (Carmeliet \& Jain, 2000). During angiogenic sprouting, the process that has been most extensively studied, endothelial cell activation, migration and proliferation take place in a highly orchestrated manner. Blood vessel maturation occurs via migration and support of pericytes and local changes in growth factor composition.

The switch to the angiogenic phenotype involves a change in balance between pro- and antiangiogenic factors which can occur at any stage of tumor progression. Vascular endothelial growth factor (VEGF) is quickly produced by tumor cells as a result of hypoxia or oncogenic transformation but can also be locally delivered by leukocytes. It signals mainly through VEGF receptor (VEGFR)-2 to activate a network of kinases and other downstream effectors, leading to endothelial cell migration, proliferation and survival (Ferrara et al., 2003). The importance of VEGF for angiogenesis control was shown more than a decade ago in a pre-clinical study where administration of VEGF neutralizing antibodies resulted in strong inhibition of tumor outgrowth (Kim et al., 1993). Recently, its potential as a target for anti-angiogenic cancer therapy was also demonstrated in the clinic (Hurwitz et al., 2004; Willett et al., 2004).

VEGF-R2 based induction of inducible NO synthase (iNOS) activity is considered to be essential in early stage vessel dilation, which likely acts in conjunction with the release of VE-cadherin from its actin anchor, leading to increased endothelial permeability (Weis et al., 2004). Subsequently, the basement membrane of the capillary bed is degraded by matrix metalloproteinases (MMPs), allowing serum components to leak out of the vessel and to form a provisional matrix onto which endothelial cells can migrate into the tissue.

Upon hypoxia, local angiopoietin (Ang)-2 production is also increased, as a result of which it can compete with Ang-1 for their mutual Tie-2 receptor. Consequently, the endothelial cells become responsive to growth factors (Ramsauer \& D'Amore, 2002). Besides induction of its ligand, Tie-2 receptor expression can also be modulated by hypoxia (Willam et al., 2000). During the course of neovessel formation, prevention of endothelial apoptosis is effected by VEGF-R2 as well as $\alpha \mathrm{v} \beta 3$ integrin-mediated signal transduction (Stromblad et al., 1996). Furthermore $\alpha v \beta 3$ integrin ligation upregulates MMP-2 to induce endothelial cell invasion (Silletti et al., 2001)

After cellular proliferation, functional blood vessels should form. Maturation of the newly formed vessels is controlled via the recruitment of pericytes and the formation of new extracellular matrix components. This process is also tightly controlled by the spatiotemporal expression of cytokines, growth factors and their respective receptors, with the main factors involved being platelet derived growth factor, transforming growth factor- $\beta$, Ang-1 and sphingosine-phosphate (Jain, 2003). Furthermore, during the different stages of angiogenesis, different basement membrane components actively regulate endothelial cell responses (Kalluri, 2003).

\section{TARGET EPITOPES ON TUMOR ENDOTHELIAL CELLS}

One of the main determinants of the therapeutic success of drug-targeting is the selectivity of the cellular target molecule in combination with the homing ligand in the targeting construct. In theory, any protein expressed in the membrane of the tumor endothelial cells can serve as a target provided it is absent from other cells in the body. The first molecular targets on tumor endothelial cells were identified while unravelling endothelial cell behavior during the neovascularization process. Later on, the search for targets moved toward investigations using methods like phage display (Rajotte et al., 1998) and serial analysis of gene expression or SAGE (St Croix et al., 2000), for which no prior knowledge of the target epitope identity or function is required. In Table 1, putative target epitopes on tumor endothelial cells reported in the last two decades are summarized.

Based on a detailed understanding of the function of the molecules during normal physiological and pathophysiological conditions, they can be selected as a target for further study for vascular drug-targeting. Essential in this respect is knowledge on their expression patterns in other vascular beds and on other cells in the body. By this means, one can either ensure selectivity of the target or 
Table 1. Epitopes on angiogenic endothelial cells and basement membrane components that in theory may serve as targets for tumor vasculature-selective drug-targeting strategies.

*Denotes the target molecules experimentally employed for tumor vascular drug-targeting strategies. A selection of these strategies is detailed in the text.

\begin{tabular}{ll}
\hline Target & Reference \\
\hline 30.5 kDa antigen & Hagemeier et al., 1986 \\
CD34 & Schlingemann et al., 1990 \\
${ }^{*}$ VEGF-VEGFR complex & Brown et al., 1993 \\
Endosialin & Rettig et al., 1992 \\
*Selectins & Nguyen et al., 1993 \\
${ }^{*}$ av integrins & Brooks et al., 1994 \\
${ }^{*}$ Endoglin & Burrows et al., 1995 \\
Tie-2 & Sato et al., 1995 \\
Angiostatin receptor & Moser et al., 1999 \\
${ }^{*}$ MMP-2 / MMP-9 & Koivunen et al., 1999 \\
*CD13 / Aminopeptidase N & Pasqualini et al., 2000 \\
Endostatin receptor & Karumanchi et al., 2001 \\
TEM 1/5/8 & St Croix et al., 2000 \\
${ }^{*}$ VE cadherin cryptic epitope & Corada et al., 2002 \\
CD44v3 & Forster-Horvath et al., 2004 \\
Annexin A1 & Oh et al., 2004 \\
\hline Inducible target & \\
P-selectin & Hallahan et al., 1998 \\
\hline Extracellular matrix target & \\
${ }^{*}$ EDB-Fn & Tarli et al., 1999 \\
Basement membrane com- & Epstein et al., 1995 \\
ponent & \\
\hline
\end{tabular}

Abbreviations used: EDB-Fn, EDB-oncofetal domain of fibronectin; MMP, matrix metalloproteinase; TEM, tumor endothelial marker; $\operatorname{VEGF(R),~vascular~endothelial~cell~growth~factor~(receptor).~}$

identify the places in the body where potential side effects can occur. Furthermore, knowledge regarding cellular handling after ligand binding is essential, as it determines the choice of effector molecules to be delivered. In the case of using, e.g., bacterial toxins, toxic drugs, or plasmids encoding therapeutic proteins, intracellular delivery is a prerequisite, as their effects are exerted in the cells' interior. This implies that the target epitope needs to be internalized upon binding of the drug-targeting construct. In contrast, for blockade of tumor blood flow by selective delivery of a blood coagulation-inducing protein or by cytotoxic $\mathrm{T}$ lymphocyte-mediated killing of the tumor endothelium, delivery of the effector at the outer membrane of the tumor endothelium suffices.

\section{TARGETED TUMOR INFARCTION}

In general, tumor vasculature-directed therapies either aim at tumor blood flow inhibition, interference with endothelial angiogenic behaviour, or at the direct induction of tumor endothelial cell death. Interference with angiogenic signal transduction pathways often indirectly leads to endothelial cell death due to apoptosis induction. The therapeutic potentials of approaches aiming to interfere with the blood supply can be easily appreciated when considering the fact that in tumors often hundreds of tumor cells are fed by only a few blood vessels (Fig. 3). The number of endothelial target cells is limited, in contrast to the number of tumor cells to be killed by a tumor cell-directed approach. Furthermore, accessibility of the tumor endothelium is significantly better compared to that of tumor cells, with many layers of tumor cells being often nurtured by only one blood vessel. Hitting the tumor at the level of its blood supply is therefore considered as hitting the tumor at its most vulnerable component. The following sections focus on targeted delivery of effector molecules that are able to block tumor blood flow, either by induction of blood coagulation in the tumor blood vessels or induction of tumor endothelial cell death.

One of the first papers demonstrating the potential of tumor endothelial cell killing and consequent local blood flow blockade to inhibit tumor outgrowth employed immunotoxins aimed at an artificially upregulated target on mouse tumor endothelium, major histocompatibility complex (MHC) class II (Burrows \& Thorpe, 1993). In the same tumor model, MHC class II antibody mediated delivery of a truncated form of the activator of the extrinsic pathway of blood coagulation, tissue factor, led to a massive debulking of large tumor masses (Huang et al., 1997). These proof-of-concept studies supported the hypothesis put forward more than three decades ago that selectively interfering with the tumor blood supply would lead to strong anti-tumor effects. While the studies referred to above were executed in mice in which the tumor (endothelial) cells were genetically altered to provide suitable targets, these were rapidly followed by new studies employing endogenous targets on tumor endothelial cells.

Both the anti-vascular cell adhesion molecule (VCAM)-1 antibody-targeted truncated tissue factor study (Ran et al., 1998) and the anti-EDB oncofetal domain of fibronectin (EDB-Fn) antibody domaintargeted tissue factor study (Nilsson et al., 2001) corroborated the data on the therapeutic efficacy of the first local tumor infarction studies. Of importance is that the success of the so called coaguligand strategies was strongly dependent on the percentage of tumor blood vessels that became infarcted. In an elegant study, $\mathrm{Hu}$ and colleagues (2003) compared the therapeutic potency of three recombinant fusion proteins consisting of truncated tissue factor and antibodies against either DNA expressed in degenerative areas, or fibronectin in the tumor vessel basement membrane, or an arginine-glycine-aspartic acid (RGD) sequence specific for $\alpha \mathrm{v}$ integrins (see below). Interestingly, while fibronectin- and $\alpha \mathrm{v}$-targeted tissue factor induced thrombosis in small and medium 
sized vessels, DNA-targeted tissue factor did so in larger vessels. Combining all three coaguligands was the most effective treatment strategy to inhibit tumor outgrowth. Since in many tumors endothelial heterogeneity at different stages of tumor growth is likely cause of lack of therapeutic success of a monotarget therapy, a multi-target approach seems to be indicated for further development.

\section{TARGETED TUMOR ENDOTHELIAL CELL KILLING}

Another seminal study showing the therapeutic potential of killing tumor vascular endothelium used two different mouse tumor models. In one model the enzyme thymidine kinase was selectively expressed in tumor endothelium, whereas in the other model this enzyme was expressed in tumor cells only. Subsequent treatment with Ganciclovir induced cytotoxicity in the endothelial cells and in the tumor cells, respectively. It was shown that the anti-tumor effects of killing the endothelium, representing only $5 \%$ of the cell volume in the tumor tissue, were similar to the effects of killing $50 \%$ of the tumor cells (Mavria \& Porter, 2001).

To date, $\alpha v \beta 3$ integrin, VEGF-Rs and the EDB domain of fibronectin have been extensively studied as targets for the delivery of toxic drugs into tumor endothelial cells. Without trying to be comprehensive, some of the studies reported are briefly discussed below.

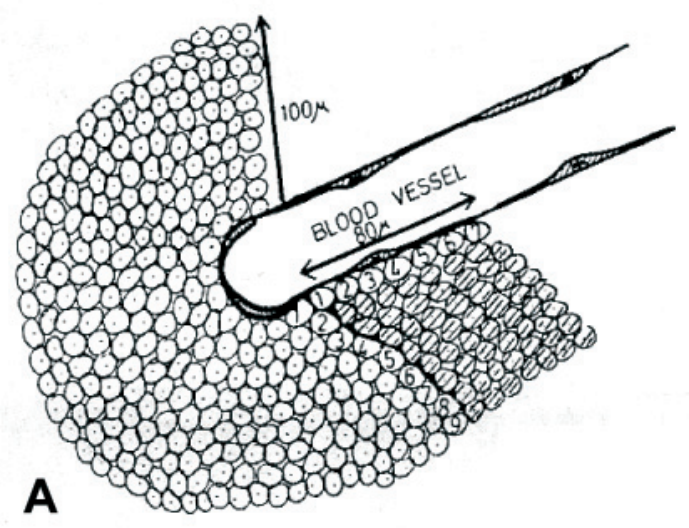

\section{RGD-based approaches}

Chemically constrained RGD-peptides preferentially bind $\alpha v \beta 3 / \alpha v \beta 5$ integrin expressed on proliferating tumor endothelial cells, besides their intrinsic binding specificity for $\alpha v \beta 3$ on macrophage subsets in liver and spleen. When conjugated to the chemotherapeutic drug doxorubicin or the apoptosis inducing peptide (KLAKLAK) ${ }_{2}$ strong anti-tumor effects could be brought about in vivo (Arap et al., 1998; Ellerby et al., 1999).

To obtain an $\alpha v \beta 3 / \alpha v \beta 5$ specific macromolecular carrier protein with high drug loading capacity and improved pharmacokinetic behavior, we chemically conjugated cRGDfK peptides to a $150 \mathrm{kDa}$ immunoglobulin protein backbone. The multivalent derivatives displayed a more than 1200-fold increased affinity for $\alpha v \beta 3 / \alpha v \beta 5$ integrins on endothelial cells when the peptide : protein ratio was about 22:1 (Kok et al., 2002). Using this approach, we constructed RGD-anti-CD3 antibodies that could redirect the cell killing activity of cytotoxic $\mathrm{T}$ lymphocytes to proliferating endothelium (Schraa et al., 2004). The thus created macromolecular RGD-proteins exhibited improved pharmacokinetic behavior, as reflected by a plasma half life in mice of approximately $90 \mathrm{~min}$. In s.c. tumors in mice, the RGD-protein conjugates selectively localized at the tumor vascular endothelium (Schraa et al., 2002b).

Similar targeting strategies were employed for gene delivery purposes. High molecular mass polymeric conjugates of an RGD-peptide and a cationic polymer complexed with a plasmid encoding a mu-

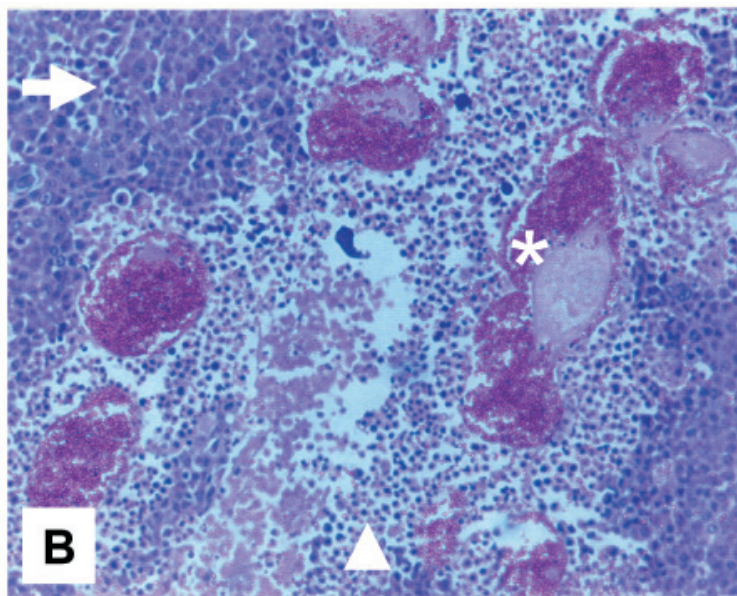

Figure 3. Therapeutic potential of tumor vasculature-directed drug-targeting strategies.

A. Many tumors consist of numerous layers of tumor cells fed by one blood vessel. By selectively interfering with blood vessel function via, e.g., the induction of local blood coagulation, hundreds of tumor cells will be deprived of oxygen and nutrients, as a result of which they will die (adapted from Denekamp, 1984). B. Selective delivery of truncated tissue factor, a blood coagulation inducing factor, locally at the tumor vascular endothelial membrane in mice, completely infarcted blood vessels in the tumor (asterisk denotes a tissue factor induced fibrin clot in a blood vessel filled with erythrocytes). As a result, several layers of tumor cells (arrow head) were killed within $24 \mathrm{~h}$ after treatment (unpublished, see Huang et al., 1997 for experimental details). Tumor cells fed by blood vessels in which the endothelium did not express the target epitopes were not affected (arrow). For therapeutic success, the majority of tumor vessels should become infarcted. 
tant Raf protein inhibiting endothelial cell survival signalling, or with siRNA specifically knockingdown VEGFR-2 expression, induced tumor regression and inhibition of tumor outgrowth, respectively (Hood et al., 2002; Schiffelers et al., 2004).

\section{VEGF-based approaches}

Angiotoxins are therapeutics consisting of angiogenesis-related carrier molecules conjugated to toxin molecules. One example of angiotoxins developed for the selective killing of tumor endothelial cell is the group comprising VEGF as a carrier molecule. Upon binding to VEGF-R2 over-expressed on tumor neovasculature, the VEGF/VEGF-R complex is internalized. This makes VEGF protein a suitable carrier for the intracellular delivery of pharmacologically active drugs or toxins. Both chemical conjugates of diptheria toxin (DT) and VEGF protein (Olson et al., 1997), and recombinant fusion proteins of $\mathrm{VEGF}_{165}$ or VEGF VI21 $_{12}$ and DT translocation and enzymatic domain (Arora et al., 1999) have been reported.

Cell therapy to selectively kill tumor endothelial cells via VEGF specificity has been attempted in different ways. By immunizing mice with dendritic cells pulsed with soluble VEGF-R2, the animals developed both an antibody and a cytotoxic $\mathrm{T}$ lymphocyte response to VEGF-R2. As a consequence, tumor induced angiogenesis was blocked and development of pulmonary metastases could be prevented. Interestingly, in the immunized mice the cellular processes involved in wound healing were not affected (Li et al., 2002).

By ex vivo transfecting cytotoxic $\mathrm{T}$ lymphocytes with a construct encoding the VEGF-T cell receptor zeta chain, the cytolytic activity was selectively redirected to VEGF-R2 expressing cells, leading to strong anti-tumor effects in vivo (Niederman et al., 2002). The main advantages of redirecting cellular therapy to tumor endothelial cells instead of to tumor cells as employed in earlier immunotherapeutical approaches (Withoff et al., 2001) include better accessibility of the target cells, a limited number of target cells to be killed, and the absence of immunosuppressive conditions locally at the level of the endothelium.

\section{EDB-Fn domain-targeted approaches}

Fibronectin is an extracellular matrix component. The fibronectin isoform containing type III repeat extradomain B (EDB-Fn) is a marker of angiogenesis, with endothelium invading the tumor tissue migrating along extracellular matrix fibers containing EDB-Fn. Recombinant-technology-derived fusion proteins of a single chain antibody variable fragment $(\mathrm{ScFv})$ directed against EDB-Fn with mouse TNF $\alpha$ exhibited in vivo stronger anti-tumor activity than TNF $\alpha$ itself. This effect was further enhanced by combination treatment with the fusion protein and the chemotherapeutic drug melphalan (Borsi et al., 2003). In a similar way, Interleukin-2 (IL-2)-ScFv fusion proteins were prepared. Following administration in vivo, the fusion protein localized at the site of the tumor vessels, resulting in an increase in leukocyte infiltration into the tumor tissue and massive tumor cell death. Whether the targeted IL-2 also exerted a direct cytotoxic effect on the endothelial cells in the tumor could not be unequivocally established in those studies (Carnemolla et al., 2002). Of interest was the observation that the physicochemical properties of ScFvs recognizing EDB-Fn strongly affected the homing potential. Extreme isoelectric point values of $<5$ and $>9$ of those ScFvs inhibited protein extravasation, possibly by virtue of electrostatic interaction with the endothelium or extracellular matrix components (Melkko et al., 2002)

\section{CONCLUSIONS AND PERSPECTIVES}

Tumor vascular drug-targeting strategies aimed at directly or indirectly blocking the tumor blood flow have proven their therapeutic potential in inhibiting tumor growth and reducing tumor mass in pre-clinical tumor models. Those studies have all been performed in different animal models, being either immunocompetent or immune deficient, with different tumors growing at different sites in the body. Until now, no concerted action has been undertaken to compare the different effector strategies within one model to evaluate the relative effectiveness of the treatments. The study by $\mathrm{Hu}$ and coworkers (2003) is one of the few that addressed the efficacy of the same effector delivered at different targets on subsets of tumor endothelium.

By targeting the endothelium, the main obstacle in tumor cell-directed therapies, the endothelial barrier, has been eliminated. Yet, the heterogeneity in tumor endothelial cell behavior within a clinically relevant tumor mass and between different tumors is a serious problem resulting from the concomitant presence of blood vessels in different angiogenic stages. Furthermore, the recently reported genetic abnormalities in tumor endothelial cells (Hida et al., 2004; Streubel et al., 2004) and the existence of mosaic tumor vessels in which endothelial cells and tumor cells form the luminal surface of the neovessels (Chang et al., 2000) may all contribute to the inferior responses to anti-vascular therapy in established tumors. Pre-clinical investigations on the anti-tumor efficacy of multi-target approaches in clinically relevant tumor masses are crucial for the rational development of successful clinical strategies for the future. A thorough inventory of the molecular basis of tumor vascular heterogeneity paralleled by immuno- 
histochemical analyses of patient tumor biopsies for expression of target epitopes under study will be essential in this development.

\section{REFERENCES}

Arap W, Pasqualini R, Ruoslahti E (1998) Cancer treatment by targeted drug delivery to tumor vasculature in a mouse model. Science 279: 377-380.

Arora N, Masood R, Zheng T, Cai J, Smith DL, Gill PS (1999) Vascular endothelial growth factor chimeric toxin is highly active against endothelial cells. Cancer Res 59: $183-188$.

Bergers G, Benjamin LE (2003) Tumorigenesis and the angiogenic switch. Nat Rev Cancer 3: 401-410.

Borsi L, Balza E, Carnemolla B, Sassi F, Castellani P, Berndt A, Kosmehl H, Biro A, Siri A, Orecchia P, Grassi J, Neri D, Zardi L (2003) Selective targeted delivery of TNFalpha to tumor blood vessels. Blood 102: 4384-4392.

Brooks PC, Montgomery AM, Rosenfeld M, Reisfeld RA, Hu T, Klier G, Cheresh DA (1994) Integrin alpha v beta 3 antagonists promote tumor regression by inducing apoptosis of angiogenic blood vessels. Cell 79: 1157-1164.

Brown LF, Berse B, Jackman RW, Tognazzi K, Manseau EJ, Dvorak HF, Senger DR (1993) Increased expression of vascular permeability factor (vascular endothelial growth factor) and its receptors in kidney and bladder carcinomas. Am J Pathol 143: 1255-1262.

Burrows FJ, Tazzari PL, Amlot P, Gazdar AF, Derbyshire EJ, King SW, Vitetta ES, Thorpe PE (1995) Endoglin is an endothelial cell proliferation marker that is selectively expressed in tumor vasculature. Clin Cancer Res 1: $1623-1634$.

Burrows FJ, Thorpe PE (1993) Eradication of large solid tumors in mice with an immunotoxin directed against tumor vasculature. Proc Natl Acad Sci USA 90: 89969000.

Carmeliet P, Jain RK (2000) Angiogenesis in cancer and other diseases. Nature 407: 249-257.

Carnemolla B, Borsi L, Balza E, Castellani P, Meazza R, Berndt A, Ferrini S, Kosmehl H, Neri D, Zardi L (2002) Enhancement of the antitumor properties of interleukin-2 by its targeted delivery to the tumor blood vessel extracellular matrix. Blood 99: 1659-1665.

Chang YS, di Tomaso E, McDonald DM, Jones R, Jain RK, Munn LL (2000) Mosaic blood vessels in tumors: frequency of cancer cells in contact with flowing blood. Proc Natl Acad Sci USA 97: 14608-14613.

Corada M, Zanetta L, Orsenigo F, Breviario F, Lampugnani MG, Bernasconi S, Liao F, Hicklin DJ, Bohlen P, Dejana E (2002) A monoclonal antibody to vascular endothelial-cadherin inhibits tumor angiogenesis without side effects on endothelial permeability. Blood 100: 905-911.

Denekamp J (1984) Vascular endothelium as the vulnerable element in tumours. Acta Radiol Oncol 23: 217-225.

Ellerby HM, Arap W, Ellerby LM, Kain R, Andrusiak R, Rio GD, Krajewski S, Lombardo CR, Rao R, Ruoslahti E, Bredesen DE, Pasqualini R (1999) Anti-cancer activity of targeted pro-apoptotic peptides. Nat Med 5: 1032-1038.

Epstein AL, Khawli LA, Hornick JL, Taylor CR (1995) Identification of a monoclonal antibody, TV-1, directed against the basement membrane of tumor vessels, and its use to enhance the delivery of macromolecules to tumors after conjugation with interleukin 2. Cancer Res 55: 2673-2680.
Everts M, Koning GA, Kok RJ, Asgeirsdottir SA, Vestweber D, Meijer DKF, Storm G, Molema G (2003) In vitro cellular handling and in vivo targeting of E-selectin directed immunoconjugates and immuno-liposomes used for drug delivery to inflamed endothelium. Pharm Res 20: $64-72$

Fearon U, Griosios K, Fraser A, Reece R, Emery P, Jones PF, Veale DJ (2003) Angiopoietins, growth factors, and vascular morphology in early arthritis. J Rheumatol 30: 260-268.

Ferrara N, Gerber HP, LeCouter J (2003) The biology of VEGF and its receptors. Nat Med 9: 669-676.

Forster-Horvath C, Meszaros L, Raso E, Dome B, Ladanyi A, Morini M, Albini A, Timar J (2004) Expression of CD44v3 protein in human endothelial cells in vitro and in tumoral microvessels in vivo. Microvasc Res 68: 110-118.

Hagemeier HH, Vollmer E, Goerdt S, Schulze Osthoff K, Sorg C (1986) A monoclonal antibody reacting with endothelial cells of budding vessels in tumors and inflammatory tissues, and non-reactive with normal adult tissues. Int J Cancer 38: 481-488.

Hallahan DE, Staba Hogan MJ, Virudachalam S, Kolchinsky A (1998) X-ray-induced P-selectin localization to the lumen of tumor blood vessels. Cancer Res 58: 5216 5220.

Hellstrom M, Gerhardt H, Kalen M, Li X, Eriksson U, Wolburg H, Betsholtz C (2001) Lack of pericytes leads to endothelial hyperplasia and abnormal vascular morphogenesis. J Cell Biol 153: 543-553.

Hida K, Hida Y, Amin DN, Flint AF, Panigrahy D, Morton CC, Klagsbrun M (2004) Tumor-associated endothelial cells with cytogenetic abnormalities. Cancer Res 64: 8249-8255.

Hood JD, Bednarski M, Frausto R, Guccione S, Reisfeld RA, Xiang R, Cheresh DA (2002) Tumor regression by targeted gene delivery to the neovasculature. Science 296: 2404-2407.

Hu P, Yan J, Sharifi J, Bai T, Khawli LA, Epstein AL (2003) Comparison of three different targeted tissue factor fusion proteins for inducing tumor vessel thrombosis. Cancer Res 63: 5046-5053.

Huang X, Molema G, King S, Watkins L, Edgington TS, Thorpe PE (1997) Tumor infarction in mice by antibody-directed targeting of tissue factor to tumor vasculature. Science 275: 547-550.

Hurwitz H, Fehrenbacher L, Novotny W, Cartwright T, Hainsworth J, Heim W, Berlin J, Baron A, Griffing S, Holmgren E, Ferrara N, Fyfe G, Rogers B, Ross R, Kabbinavar F (2004) Bevacizumab plus irinotecan, fluorouracil, and leucovorin for metastatic colorectal cancer. $N$ Engl J Med 350: 2335-2342.

Jain RK (2003) Molecular regulation of vessel maturation. Nat Med 9: 685-693.

Kalluri R (2003) Basement membranes: structure assembly and role in tumour angiogenesis. Nat Rev Cancer 3: 422-433.

Karumanchi SA, Jha V, Ramchandran R, Karihaloo A, Tsiokas L, Chan B, Dhanabal M, Hanai JI, Venkataraman G, Shriver Z, Keiser N, Kalluri R, Zeng H, Mukhopadhyay D, Chen RL, Lander AD, Hagihara K, Yamaguchi Y, Sasisekharan R, Cantley L, Sukhatme VP (2001) Cell surface glypicans are low-affinity endostatin receptors. Mol Cell 7: 811-822.

Kim KJ, Li B, Winer J, Armanini M, Gillett N, Phillips HS, Ferrara N (1993) Inhibition of vascular endothelial growth factor-induced angiogenesis suppresses tumour growth in vivo. Nature 362: 841-844.

Koivunen E, Arap W, Valtanen H, Rainisalo A, Medina OP, Heikkila P, Kantor C, Gahmberg CG, Salo T, Kont- 
tinen YT, Sorsa T, Ruoslahti E, Pasqualini R (1999) Tumor targeting with a selective gelatinase inhibitor. Nat Biotechnol 17: 768-774.

Kok RJ, Ásgeirsdóttir SA, Verweij WR (2001) Development of proteinaceous drug-targeting constructs using chemical and recombinant DNA approaches. In Drug-Targeting - Organ Specific Strategies, Molema G, Meijer DKF, eds. pp 275-308, Wiley-VCH, Weinheim, New York.

Kok RJ, Schraa AJ, Bos EJ, Moorlag HE, Ásgeirsdóttir SA, Everts M, Meijer DKF, Molema G (2002) Preparation and functional evaluation of RGD-modified proteins as alpha(v)beta(3) integrin directed therapeutics. Bioconjug Chem 13: 128-135.

Li Y, Wang MN, Li H, King KD, Bassi R, Sun H, Santiago A, Hooper AT, Bohlen P, Hicklin DJ (2002) Active immunization against the vascular endothelial growth factor receptor flk1 inhibits tumor angiogenesis and metastasis. J Exp Med 195: 1575-1584.

Maeda H, Wu J, Sawa T, Matsumura Y, Hori K (2000) Tumor vascular permeability and the EPR effect in macromolecular therapeutics: a review. J Contr Rel 65: 271-284.

Mavria G, Porter CD (2001) Reduced growth in response to ganciclovir treatment of subcutaneous xenografts expressing HSV-tk in the vascular compartment. Gene Ther 8: 913-920.

Melkko S, Halin C, Borsi L, Zardi L, Neri D (2002) An antibody-calmodulin fusion protein reveals a functional dependence between macromolecular isoelectric point and tumor targeting performance. Int I Radiat Oncol Biol Phys 54: 1485-1490.

Molema G, Meijer DKF (2001) Drug-Targeting: Organ-Specific Strategies, Wiley-VCH, Weinheim.

Moser TL, Stack MS, Asplin I, Enghild JJ, Hojrup P, Everitt L, Hubchak S, Schnaper HW, Pizzo SV (1999) Angiostatin binds ATP synthase on the surface of human endothelial cells. Proc Natl Acad Sci USA 96: 2811-2816.

Mutuberria R, Arends JW, Griffioen AW, Hoogenboom HR (2001) Phage display technology for target discovery in drug delivery research. In Drug-Targeting - Organ Specific Strategies, Molema G, Meijer DKF, eds. pp 255-273, Wiley-VCH, Weinheim, New York.

Nguyen M, Strubel NA, Bischoff J (1993) A role for sialyl Lewis-X/A glycoconjugates in capillary morphogenesis. Nature 365: 267-269.

Niederman TM, Ghogawala Z, Carter BS, Tompkins HS, Russell MM, Mulligan RC (2002) Antitumor activity of cytotoxic $\mathrm{T}$ lymphocytes engineered to target vascular endothelial growth factor receptors. Proc Natl Acad Sci USA 99: 7009-7014.

Nilsson F, Kosmehl H, Zardi L, Neri D (2001) Targeted delivery of tissue factor to the ED-B domain of fibronectin, a marker of angiogenesis, mediates the infarction of solid tumors in mice. Cancer Res 61: 711-716.

Oh P, Li Y, Yu J, Durr E, Krasinska KM, Carver LA, Testa JE, Schnitzer JE (2004) Subtractive proteomic mapping of the endothelial surface in lung and solid tumours for tissue-specific therapy. Nature 429: 629-635.

Olson TA, Mohanraj D, Roy S, Ramakrishnan S (1997) Targeting the tumor vasculature: inhibition of tumor growth by a vascular endothelial growth factor-toxin conjugate. Int J Cancer 73: 865-870.

Paleolog EM (2002) Angiogenesis in rheumatoid arthritis. Arthritis Res. 4 Suppl 3: S81-S90.

Pasqualini R, Koivunen E, Kain R, Lahdenranta J, Sakamoto M, Stryhn A, Ashmun RA, Shapiro LH, Arap W, Ruoslahti E (2000) Aminopeptidase N is a receptor for tumor-homing peptides and a target for inhibiting angiogenesis. Cancer Res 60: 722-727.
Pober JS (2002) Endothelial activation: intracellular signaling pathways. Arthritis Res 4 Suppl 3: S109-S116.

Rajotte D, Arap W, Hagedorn M, Koivunen E, Pasqualini R, Ruoslahti E (1998) Molecular heterogeneity of the vascular endothelium revealed by in vivo phage display. J Clin Invest 102: 430-437.

Ramsauer M, D'Amore PA (2002) Getting Tie(2)d up in angiogenesis. J Clin Invest 110: 1615-1617.

Ran S, Gao B, Duffy S, Watkins L, Rote N, Thorpe PE (1998) Infarction of solid Hodgkin's tumors in mice by antibody-directed targeting of tissue factor to tumor vasculature. Cancer Res 58: 4646-4653.

Reinders ME, Sho M, Robertson SW, Geehan CS, Briscoe DM (2003) Proangiogenic function of CD40 ligandCD40 interactions. I Immunol 171: 1534-1541.

Rettig WJ, Garin Chesa P, Healey JH, Su SL, Jaffe EA, Old LJ (1992) Identification of endosialin, a cell surface glycoprotein of vascular endothelial cells in human cancer. Proc Natl Acad Sci USA 89: 10832-10836.

Sato TN, Tozawa Y, Deutsch U, Wolburg Buchholz K, Fujiwara Y, Gendron Maguire M, Gridley T, Wolburg H, Risau W, Qin Y (1995) Distinct roles of the receptor tyrosine kinases Tie-1 and Tie-2 in blood vessel formation. Nature 376: 70-74.

Schiffelers RM, Ansari A, Xu J, Zhou Q, Tang Q, Storm G, Molema G, Lu PY, Scaria P, Woodle MC (2004) Cancer siRNA therapy by tumor selective delivery with ligand-targeted sterically stabilized nanoparticle. Nucleic Acids Res 32: e149.

Schlingemann RO, Rietveld FJ, De Waal RM, Bradley NJ, Skene AI, Davies AJ, Greaves MF, Denekamp J, Ruiter DJ (1990) Leukocyte antigen CD34 is expressed by a subset of cultured endothelial cells and on endothelial abluminal microprocesses in the tumor stroma. Lab Invest 62: 690-696.

Schraa AJ, Everts M, Kok RJ, Asgeirsdottir SA, Molema G (2002a) Development of vasculature targeting strategies for the treatment of cancer and chronic inflammatory diseases. Biotechnology Annu Rev 8: 133-165.

Schraa AJ, Kok RJ, Moorlag HE, Bos EJ, Proost JH, Meijer DKF, de Leij LFMH, Molema G (2002b) Targeting of RGD-modified proteins to tumor vasculature: a pharmacokinetic and cellular distribution study. Int I Cancer 102: 469-475.

Schraa AJ, Kok RJ, Botter SM, Withoff S, Meijer DKF, de Leij LFMH, Molema G (2004) RGD-modified anti-CD3 antibodies redirect cytolytic capacity of cytotoxic $\mathrm{T}$ lymphocytes toward alphav-beta3 expressing endothelial cells. Int J Cancer 112: 285.

Silletti S, Kessler T, Goldberg J, Boger DL, Cheresh DA (2001) Disruption of matrix metalloproteinase 2 binding to integrin alpha vbeta 3 by an organic molecule inhibits angiogenesis and tumor growth in vivo. Proc Natl Acad Sci USA 98: 119-124.

St Croix B, Rago C, Velculescu V, Traverso G, Romans KE, Montgomery E, Lal A, Riggins GJ, Lengauer C, Vogelstein B, Kinzler KW (2000) Genes expressed in human tumor endothelium. Science 289: 1197-1202.

Streubel B, Chott A, Huber D, Exner M, Jager U, Wagner O, Schwarzinger I (2004) Lymphoma-specific genetic aberrations in microvascular endothelial cells in B-cell lymphomas. N Eng J Med 351: 250-259.

Stromblad S, Becker JC, Yebra M, Brooks PC, Cheresh DA (1996) Suppression of p53 activity and p21WAF1/CIP1 expression by vascular cell integrin alphaVbeta3 during angiogenesis. J Clin Invest 98: 426-433.

Tarli L, Balza E, Viti F, Borsi L, Castellani P, Berndorff D, Dinkelborg L, Neri D, Zardi L (1999) A high-affinity human antibody that targets tumoral blood vessels. Blood 94: 192-198. 
Vane JR, Borne GVR, Welzel D (1995) The Endothelial Cell in Health and Disease. Schattauer Verlagsgesellschaft $\mathrm{mbH}$. Stuttgart.

Von Andrian UH, Mackay CR (2000) T-cell function and migration. Two sides of the same coin. N Engl I Med 343: 1020-1034.

Voronov E, Shouval DS, Krelin Y, Cagnano E, Benharroch D, Iwakura Y, Dinarello CA, Apte RN (2003) IL-1 is required for tumor invasiveness and angiogenesis. Proc Natl Acad Sci USA 100: 2645-2650.

Weis S, Shintani S, Weber A, Kirchmair R, Wood M, Cravens $A$, McSharry $H$, Iwakura A, Yoon YS, Himes N, Burstein D, Doukas J, Soll R, Losordo D, Cheresh D (2004) Src blockade stabilizes a Flk/cadherin complex, reducing edema and tissue injury following myocardial infarction. J Clin Invest 113: 885-894.

Willam C, Koehne P, Jurgensen JS, Grafe M, Wagner KD, Bachmann S, Frei U, Eckardt KU (2000) Tie2 receptor expression is stimulated by hypoxia and proinflammatory cytokines in human endothelial cells. Circ Res 87: 370-377.

Willett CG, Boucher Y, di Tomaso E, Duda DG, Munn LL, Tong RT, Chung DC, Sahani DV, Kalva SP, Kozin SV, Mino M, Cohen KS, Scadden DT, Hartford AC, Fischman AJ, Clark JW, Ryan DP, Zhu AX, Blaszkowsky LS, Chen HX, Shellito PC, Lauwers GY, Jain RK (2004) Direct evidence that the VEGF-specific antibody bevacizumab has antivascular effects in human rectal cancer. Nat Med 10: 145-147.

Withoff S, Helfrich W, de Leij LFMH, Molema G (2001) Bispecific antibody therapy for the treatment of cancer. Curr Opin Mol Ther 3: 53-62. 